\title{
Influence of an educational strategy to promote the use of regional food
}

\author{
Influência de uma estratégia educativa na promoção do uso de alimentos regionais \\ Influencia de una estrategia educativa en la promoción del uso de alimentos regionales
}

Mariana Cavalcante Martins ${ }^{1}$, Ádria Marcela Vieira Ferreira ${ }^{1}$, Ludmila Alves do Nascimento ${ }^{1}$, Julliana dos Santos Aires ${ }^{1}$, Paulo César de Almeida ${ }^{2}$, Lorena Barbosa Ximenes ${ }^{1}$

Objective: to assess the knowledge, attitude and practice of family members of preschool children about regional food, through a survey before and after an educational intervention. Methods: this is a pre-experimental one-group pretestposttest study, with 62 family members of preschool children. One month before and after the conduction of an educational activity using the flipchart "regional food promoting food security", one applied the survey. Results: it was found that after the educational strategy, there was an increase in the classification "appropriate" in each survey area about regional food, and the variation of knowledge (17.7\%-77.4\%), attitude (21\%-72.6\%) and practice (14.5\%-64.5\%), consequently, an improvement of $59.7 \%$ in knowledge, $51.6 \%$ in attitude and $50 \%$ in practice. Conclusion: the use of educational technology had a positive influence on the knowledge, attitudes and practice of family members, contributing thus to the health promotion of children and their family members.

Descriptors: Health Knowledge, Attitudes, Practice; Food Habits; Health Education.

Objetivo: avaliar o conhecimento, atitude e prática dos familiares de crianças pré-escolares sobre os alimentos regionais, através de um inquérito, antes e após a intervenção educativa. Métodos: pesquisa pré-experimental de modelo de pré-teste/ pós-teste com único grupo, com 62 familiares de crianças pré-escolares. Antes e após um mês da realização da atividade educativa utilizando o álbum seriado, Alimentos regionais promovendo a segurança alimentar, aplicou-se o inquérito. Resultados: constatou-se que, após a estratégia educativa, houve um aumento na classificação "adequada" em cada eixo do inquérito sobre os alimentos regionais, sendo a variação do conhecimento (17,7\%-77,4\%), atitude (21\%-72,6\%) e prática (14,5\%-64,5\%), consequentemente, um avanço em 59,7\% no conhecimento, $51,6 \%$ na atitude e $50 \%$ na prática. Conclusão: o uso da tecnologia educativa apresentou influência positiva no conhecimento, atitude e prática dos familiares, contribuindo, assim, para a promoção da saúde da criança e da família.

Descritores: Conhecimentos, Atitudes e Práticas em Saúde; Hábitos Alimentares; Educação em Saúde.

Objetivo: evaluar conocimiento, actitud y práctica de familiares de niños preescolares sobre alimentos regionales, a través de una encuesta, antes y después de la intervención educativa. Métodos: investigación pre-experimental de modelo pretest/post-test con solo grupo, con 62 familias de niños preescolares. Antes y después de un mes de la actividad educativa mediante el álbum seriado, Alimentos regionales promoviendo la seguridad alimentaria, se aplicó la encuesta. Resultados: después de la estrategia educativa, hubo aumento de la calificación "adecuada" en cada eje de la encuesta sobre comida regional, y la variación del conocimiento $(17,7 \%-77,4 \%)$, actitud $(21 \%-72,6 \%)$ y práctica $(14,5 \%-64,5 \%)$, en consecuencia, mejora en conocimiento 59,7\%, 51,6\% en la actitud y 50\% en la práctica. Conclusión: el uso de la tecnología educativa tuvo influencia positiva en conocimiento, actitud y práctica de los familiares, contribuyendo así a la promoción de la salud del niño y la familia.

Descriptores: Conocimientos, Actitudes y Práctica en Salud; Hábitos Alimenticios; Educación en Salud.

\footnotetext{
${ }^{1}$ Universidade Federal do Ceará. Fortaleza, CE, Brazil.

${ }^{2}$ Universidade Estadual do Ceará. Fortaleza, CE, Brazil. 


\section{Introduction}

Feeding is an important practice to maintain people's life and development ${ }^{(1)}$. As a result, the characteristics of children's growth highlight the importance of feeding in their first five years of life, requiring specific care, especially regarding its quality, quantity, diversity and frequency ${ }^{(2)}$.

Currently, in Brazilians' usual diet, there is the inclusion of foods classified as ultra-processed, with high levels of fat, sodium and sugar; low in micronutrients and high in caloric content. The average consumption of fruits and vegetables is below the recommended amount by the food guide for the Brazilian population ${ }^{(3)}$. Because of this, overweight and obesity rates increased in the country over the past decade. The prevalence of overweight ranged from $26.9 \%$ to $66.8 \%$ between children from five to nine years old from 1989 to 2009. Obesity ranged from $16 \%$ to $24.8 \%$ in the same period ${ }^{(4)}$.

In this context, in a previous study conducted in Maranguape-CE one found out that children's dietary patterns, in complementary feeding had low energetic and nutritional content, with a predominant use of processed foods (instant noodles, soda and artificial juice) instead of regional food, which was used only in the preparation of juices ${ }^{(5)}$.

Regional food (fruit, vegetables, tubers and legumes) are those available in each region of Brazil and they have as primary features: easy access, low cost and high nutritional value ${ }^{(6)}$. Therefore, feeding based on a regional culture, through the consumption of these foods, is an effective alternative to fight food insecurity.

Therefore, it is essential to encourage the development of nutritional intervention strategies, inserted in the health educational field, in order to educate parents about the importance of proper nutrition for their children's development.
Then, as part of their responsibilities, it is up to health professionals to develop educational strategies that are aimed at the interaction and at the exchange of knowledge and that respect the lifestyle of each population. In this scenario, nurses' role is highlighted, in the position of educator, who becomes responsible for educational practices. And this not only an exchange of information, but rather a transformative educational practice that allows individuals to reflect and decide, especially in relation to the adoption of healthy eating habits.

Therefore this study is justified because, when one performs an educational strategy for the education of preschool children's family members, one aimed to increase their knowledge, attitudes and practices regarding regional food, as well as to encourage the widespread use of this food in families' daily lives, thus favoring children's development.

From this perspective, this study aimed to evaluate the knowledge, attitudes and practices of preschool children's families about regional food before and after the conduction of an educational intervention.

\section{Method}

This was a one-group pretest-posttest study ${ }^{(7)}$, with a quantitative approach, performed at a family health center located in a district of the rural town of Maranguape, metropolitan region of Fortaleza, Ceará, Brazil .

The population consisted of 62 family members (mothers or caregivers who provide daily care for children), who can be responsible for one or more pre-school children from the same family, identified through a household registration form (Form A), through the inclusion criteria: children attended at the health center selected; residing in the rural zone studied; and who could participate in all the research stages. 
Data collection took place in three stages. Initially, there was a home visit to invite individuals to participate in the study. Upon approval and after signing a free and informed consent form, one applied through interviews the survey about knowledge, attitudes and practices, in their own houses, and one also scheduled a subsequent meeting at the health center to conduct an educational intervention.

This survey about knowledge, attitude and practice has been used as a source for obtaining diagnosis that precedes an educational intervention, aiming to guide this action in a targeted, systematic and plausible way when it reveals knowledge, attitudes and practices on a given subject ${ }^{(8)}$. And it was drawn from previous studies ${ }^{(5.9)}$, held in the town. This survey consists of 10 questions, open and closed, and was divided into four parts: the first refers to family identification data; and the others are related to the areas of the survey: knowledge, attitudes and practices concerning regional food. It should be noted that the survey was developed and validated by two experts in the area and that a pilot test was done with 15 family members who did not participate in the research.

For building the survey, the following definitions for knowledge, attitude and practice were adopted, through a similar study ${ }^{(10)}$ : knowledge ability to recall specific facts, ability to apply them in solving problems and also give concepts with acquired understanding about a particular event; attitude act of having constant opinions, feelings and beliefs, directed to a goal, person or situation; and practice decision making to perform the action.

From these concepts, it was held an adaptation for the theme regional food. Therefore, after the responses of participants, each area of the survey knowledge, attitude and practice was classified as appropriate or inappropriate. Thus, it was considered as appropriate when the interviewee contemplated the items described in Figure 1.

\begin{tabular}{|l|l|}
\hline $\begin{array}{l}\text { Area of knowledge, } \\
\text { attitude and practice }\end{array}$ & \multicolumn{1}{|c|}{ Adaptation for the theme } \\
\hline Appropriate knowledge & $\begin{array}{l}\text { - He/she has already heard about regional food } \\
\text { - He/she mentions three types of these foods; } \\
- \text { He/she refers to, at least, two types of } \\
\text { preparation options using these foods. }\end{array}$ \\
\hline Appropriate attitude & $\begin{array}{l}\text { - He/she refers to the importance of introducing } \\
\text { it may prevent malnutrition and obesity; promote } \\
\text { food security; and be a new food alternative. }\end{array}$ \\
\hline Appropriate practice & $\begin{array}{l}\text { - He/she says that he/she has already offered } \\
\text { children some regional food; } \\
\text { included whenever it is necessary. }\end{array}$ \\
\hline
\end{tabular}

Figure 1 - Description of the levels of knowledge, attitude and practice considered as appropriate

In the second moment of the survey one conducted an educational intervention in the family health center, in which one used a flipchart - Regional food promoting food security. This album was built following the assumptions ${ }^{(5)}$ of Paulo Freire. It is composed of seven illustrations, which are exposed to the population, and by five script forms in the back, that stay visible to the professionals. The themes addressed involve food security; use of regional foods; appropriate hygiene; and the preparation options to be made with cashews, bananas, red mombin fruits and pumpkin (regional foods selected to compose the album). This educational technology was submitted to judges, obtaining figures' Content Index Validity of 0.95 and of the script forms of $0.97^{(5)}$.

The educational activity took place on the day and times scheduled previously with the participants, lasting 1 hour and 30 minutes. That moment was held in a private room, which has a table, chairs, good lighting and ventilation, characterized as a peaceful and suitable setting for the development of this stage. Family members were divided into small groups so that each one was composed of a maximum of ten 
participants. It is appropriate to point out that each individual participated only once in the educational intervention using the flipchart.

The third moment was conducted after a month of the completion of the educational activity, and consisted of a new application of the survey knowledge, attitude and practice, at the participants' homes, in days and times arranged with them. It is noteworthy that the researcher responsible for implementing the flipchart in educational groups did not participate in the step mentioned, aiming to minimize bias in the data collection.

Data were tabulated and quantified with the help of the program predictive analytics software, version 18. For the analysis, one used descriptive statistics, using absolute and relative frequencies, organized in tables, and analyzed according to studies related to the theme.

The study was approved by the ethics committee of the Federal University of Ceará [Universidade Federal do Ceará] under opinion No 98/09. All the recommendations and ethical requirements for research involving human beings were respected, according to resolution No. 196/96 and the participants signed the free and informed consent form agreeing to participate in the study.

\section{Results}

Regarding the socio-demographic conditions of the 62 family members, it was realized that all the participants were women, most were married/ had consensual union $(\mathrm{N}=46 ; 74.2 \%)$ had completed elementary school $(\mathrm{N}=32 ; 51.6 \%)$, only did home activities ( $\mathrm{N}=52 ; 83.9 \%)$ had only one preschool child $(\mathrm{N}=52 ; 83.9 \%)$ and the monthly income ranged from one to two minimum wages $(\mathrm{N}=31 ; 50 \%)$.

In Table 1, one could verify the knowledge, attitudes and practices of respondents about regional food, before and after the educational intervention.

Regarding the knowledge area, prior to the health education intervention, most of the respondents $(\mathrm{N}=54 ; 87.1 \%)$ claimed not having heard of the "regional food" terminology. Besides, they only knew traditional preparation options (juices, marmalades, smoothies, cakes, among others) with the use of regional food and those were not listed in the survey knowledge, attitudes and practices ( $\mathrm{N}=16 ; 25.8 \%)$. However, after the intervention, almost all of them $(\mathrm{N}=60 ; 96.8 \%)$ started to recognize the terminology and suggested other preparations containing these foods, being the most mentioned, the sweet potato fries $(\mathrm{N}=61,98.4 \%)$ and the cashew meat $(\mathrm{N}=43$; $69.4 \%)$.

Table 1 - Percentage distribution of families, according to the knowledge area about regional foods before and after the educational intervention

\begin{tabular}{lcc}
\hline \multirow{2}{*}{ Knowledge area } & Before & After \\
\cline { 2 - 3 } & n (\%) & n (\%) \\
\hline Has already heard about regional food & & \\
Yes & $8(12.9)$ & $60(96.8)$ \\
No & $54(87.1)$ & $2(3.2)$ \\
Knows what regional food is good for & & \\
Varied diet & $3(4.8)$ & $51(82.3)$ \\
Make juices & $14(22.6)$ & $6(9.7)$ \\
Does not know & $14(22.6)$ & $3(4.8)$ \\
Another purpose & $31(50.0)$ & $2(3.2)$ \\
Preparation options with regional food & \multicolumn{2}{c}{} \\
Cashew meat & - & $43(69.4)^{*}$ \\
Farofa with banana & - & $29(46.8)^{*}$ \\
Rice with pumpkin shell & - & $16(25.8)^{*}$ \\
Mashed pumpkin & - & $19(30.6)^{*}$ \\
Sweet potato fries & - & $61(98.4)^{*}$ \\
Red mombin's leaf juice & \multicolumn{2}{c}{$39(62.9)^{*}$} \\
Does not know or does not remember & $13(21.0)$ & $7(11.3)^{*}$ \\
Others & $49(79.0)$ & $4(6.5)^{*}$ \\
\hline It was decided to place the individual percentages of each preparation op- \\
tion because participants could name more than one &
\end{tabular}


Regarding the attitude area, it was observed that both before and after the intervention, all the respondents $(\mathrm{N}=62,100 \%)$ considered that the use of regional food in children's feeding routine is necessary, being the most mentioned reason the fact that it is strong and healthy food that contains vitamins (before: N=57; 92\% - after: N=31; 50\%). However, there was a decrease in the percentage of the previous answer (after the intervention), because more people mentioned the alternative that these foods promote food security ( $\mathrm{N}=22 ; 35.5 \%)$, a subject very discussed during the educational intervention.

Table 2 - Percentage distribution of family members according to the attitude area about regional food before and after the educational intervention

\begin{tabular}{lcc}
\hline \multirow{2}{*}{ Attitude area } & Before & After \\
\cline { 2 - 3 } & $\mathbf{n}(\%)$ & $\mathbf{n}(\%)$ \\
\hline Is regional food necessary? & $62(100.0)$ & $62(100.0)$ \\
Yes & - & - \\
No & & \\
Why is regional food necessary? & $1(1.6)$ & $7(11.3)$ \\
To prevent nutritional disorder & $3(4.8)$ & $22(35.5)$ \\
To favor food security & - & $1(1.6)$ \\
It is a new feeding alternative & & \\
It is strong and healthy, and it contains & $57(92.0)$ & $31(50.0)$ \\
vitamins & $1(1.6)$ & $1(1.6)$ \\
\hline Does not know & & \\
\hline
\end{tabular}

Regarding the practice area, it can be seen that almost all participants reported having used regional food in children's diet, both before and after the educational intervention (before: $\mathrm{N}=61 ; 98.4 \%$ after: $\mathrm{N}=58 ; 93.5 \%$ ). Also, most of them said that this food can be used whenever those responsible for the children find necessary (before $\mathrm{N}=42 ; 67.7 \%$ - after, $\mathrm{N}=51 ; 82.3 \%)$.
Table 3 - Percentage distribution of family members according to the practice area about regional foods before and after the educational intervention

\begin{tabular}{lcc}
\hline & Before & After \\
\cline { 2 - 3 } Practice area & $\mathbf{n}(\%)$ & $\mathbf{n}(\%)$ \\
\hline $\begin{array}{l}\text { Have you ever used regional food in the } \\
\text { child's meal? }\end{array}$ & & \\
Yes & $61(98.4)$ & $58(93.5)$ \\
No & $1(1.6)$ & $4(6.5)$ \\
How many times a month can regional food & & \\
be used? & & \\
Whenever necessary & $19(67.7)$ & $51(82.3)$ \\
He/she defined a number of days & $1(1.6)$ & $1(1.6)$ \\
\hline
\end{tabular}

Then, considering the criteria established to classify knowledge, attitudes and practices in appropriate and inappropriate, it can be seen that according to table 4, after the health education activity using the flipchart, there was an increase in the appropriate level in all the areas: knowledge (before $=17.7 \%$ and after $=77.4 \%$ ), attitudes (before $=21 \%$, after $=72.6 \%$ ) and practices (before $=14.5 \%$ after $=64.5 \%$ ).

Table 4 - Distribution of participants in relation to their knowledge, attitudes and practices before and after the educational intervention

\begin{tabular}{lcc}
\hline \multirow{2}{*}{ Areas Knowledge, Attitude and Practice } & Before & After \\
\cline { 2 - 3 } & $\mathbf{n}(\%)$ & $\mathbf{n}(\%)$ \\
\hline Knowledge & $11(17.7)$ & $48(77.4)$ \\
$\quad$ Appropriate & $51(82.3)$ & $14(22.6)$ \\
$\quad$ Inappropriate & & \\
Attitude & $13(21.0)$ & $45(72.6)$ \\
$\quad$ Appropriate & $49(79.0)$ & $17(27.4)$ \\
$\quad$ Inappropriate & & \\
Practice & $9(14.5)$ & $40(64.5)$ \\
$\quad$ Appropriate & $53(85.5)$ & $22(35.5)$ \\
Inappropriate & & \\
\hline
\end{tabular}




\section{Discussion}

Studies related to feeding and human nutrition have been decisive to guide programs and public health promotion policies ${ }^{(11)}$. In this sense, studies about knowledge, attitudes and practices involving this issue become important because they allow a diagnosis of the population, and shows what people know, feel and also how they behave ${ }^{(8)}$.

It is known that in order to establish a satisfactory educational practice it is essential to know the reality of the target audience, so health education should be adapted to the needs, interests and previous knowledge of each individual.

In this study, the lack of knowledge of family members when asked about "regional food" before the intervention should not be interpreted as such food is not known/consumed by the population interviewed. It is believed that probably they did not recognize the terminology used, because when this food (cashew, banana; red mombin, pumpkin, sweet potato, among others) were mentioned individually, all the participants affirmed knowing them. However, after the educational intervention, $96.8 \%$ of the individuals started to recognize that terminology.

Similarly, interviews with nine professionals who worked in a school feeding program in a city in the countryside of Bahia, Brazil sought to understand the meanings of the term "regional eating habits" and identified a number of complex responses, having been the most frequent the ones that it mentioned as being something "specific/unique to the region and that is not consumed in any other places"(12:195).

Also, before the educational activity, most participants knew only traditional preparation options (juices, marmalades, smoothies, cakes, among others) with the use of regional food. And subsequently they mentioned several preparations with that food (sweet potato fries; cashew meat, red mombin's leaf juice, among others). It is appropriate to highlight that regional food belongs to various food groups: fruits, vegetables, tubers and legumes ${ }^{(6)}$; and, because of that, there are several ways to insert it into children's eating routine.

One also highlights that the most present regional food in the area was selected (cashew, banana, pumpkin and red mombin) to compose the flipchart "Regional food promoting food security". In this technology there are recipes of preparation options with this food, which are: cashew meat; farofa with banana peel; mashed pumpkin; rice with pumpkin shell; and red mombin's leaf juice ${ }^{(5)}$. Then, with the objective of promoting children and family health, these suggestions can be offered for lunch or dinner because they are healthy, affordable and respect the region's cultural identity ${ }^{(13)}$, contributing also to encourage healthy eating habits during childhood.

A previous study conducted in the town of this study identified that the underutilization of regional food by mothers occurred due to their lack of knowledge about other preparation options with this food reiterating, then, the need to spread its benefits ${ }^{(9)}$.

In this study, one used the flipchart "regional food promoting food security" in educational activities, following the principles of problem-based education $^{(5)}$. However, the application of these teachings in educational practices is a major challenge, as many professionals may not be aware of them, and others may not be able to use them in their practice ${ }^{(14)}$.

Then, considering the importance of developing interventions about the theme children's feeding, a study in northern Greece with 54 pre-school children during three months, found that those who attended the nutritional education program modified their food choices (replacing processed food for fruit and vegetables), and one also observed a reduction in the frequency of consumption of unhealthy foods ${ }^{(15)}$.

As a complement, a study conducted with 192 children between five and six years old and their parents in Adelaide, Australia, found out that parents' knowledge about proper nutrition interfered directly in their children's knowledge; and that parents' attitude in having a healthy diet influenced indirectly in children's knowledge about the subject. 
Thus, authors believe that this knowledge acquired in childhood can influence the creation of proper eating habits $^{(16)}$.

In the present study, it was observed the opposite, as most families had no prior knowledge about regional food, however, everyone knew about the need to use it to feed their children (attitude).

Before the intervention, the option regarding the importance of this food for favoring food security was selected by only 03 (4.8\%) participants. It is suggested that this happens due to the difficulty in knowing food security terminology, because after the intervention, there was an increase of answers ( $N=22 / 35.5 \%$ ) (a very present theme in the flipchart).

Difficulty also presented in a study with 23 professionals who were interviewed about food security, as most of them did not know how to define it. Those who tried to establish a concept, associated the theme only to the services provided (assessment of children's growth and development through anthropometric measurements), dissociating the concept of food security from the right to eat of all individuals ${ }^{(17)}$.

Regarding the practice area, regional food had already been used by families in the town, even before the educational activity, remaining after its conduction. This can be justified because, according to a national survey, Brazilian people who live in the countryside, as compared to residents of urban areas, have a higher frequency of consumption of basic foods with a better quality diet, with predominance of consumption of items such as rice, beans, sweet potato, cassava, cassava flour, fruit and fish ${ }^{(3)}$.

It also shows that before the educational intervention, the majority of respondents had inappropriate level regarding knowledge (82.3\%), attitudes (79\%) and practices (85.5\%). And that, one month after its completion, the situation was reversed, as the three areas of knowledge survey, attitude and practice were classified as appropriate.
Finally, one could infer that the educational intervention carried out from the use of a flipchart influenced positively the knowledge, attitudes and practices of children's family members about the theme regional food. Therefore, it is essential the adoption of problem-based education in educational activities, as it is believed that this methodology provides immersion in the local culture and, at the same time, it creates a space for dialogue and clarification, facilitating the exchange of knowledge among those involved.

\section{Conclusion}

From this study, it is considered that the conduction of educational activities involving the theme children's feeding is relevant, given that it enabled changes in the acquisition of knowledge, attitudes and practices in relation to regional food. And with that, the use of a flipchart can be effective as there are health professionals, especially nurses, mediating the discussion among families of preschool children and encouraging the consumption of regional foods, while respecting the cultural diversity of Brazilian regions.

This study had as limitations a reduced number of informants, given the choice of a single location, being difficult to access, and the lack of monitoring of families, through the application of the survey knowledge, attitudes and practices in subsequent months, in order to check whether the educational activity using the flipchart influences permanently on families' knowledge, attitudes and practices.

Finally, it is recommended the need of a training process with the professionals involved in children's health care, so they can use the flipchart "Regional food promoting food security", thus contributing to the creation of healthy eating habits since childhood, and the promotion of children's and family's health. 


\section{Collaborations}

Martins MC contributed to the work design, data collection, analysis, data interpretation and writing of the article. Ferreira AMV, Nascimento LA and Aires JS contributed to the data collection, data interpretation and work design and final version to be published. Almeida PC performed the tabulation and statistical analysis. Ximenes LB participated in the construction of the project, review and critical analysis of the article.

\section{References}

1. Osorio-Murillo O, Amaya-Rey MCP. Laalimentación de los adolescentes: el lugar y la compañía determinan las prácticas alimentarias. Aquichan. 2011; 11(2):199-216.

2. Costa MGFA, Nunes MMJC, Duarte JC, Pereira AMS. Conhecimento dos pais sobre alimentação: construção e validação de um questionário de alimentação infantil. Rev Enf Ref. 2012; (6):55-68.

3. Ministério da Saúde (BR). Política Nacional de Alimentação e Nutrição. Brasília: Ministério da Saúde; 2012.

4. Instituto Brasileiro de Geografia e Estatística. Pesquisa de Orçamentos Familiares 2008-2009: Antropometria e análise do estado nutricional de crianças, adolescentes e adultos no Brasil. Rio de Janeiro: IBGE: 2009.

5. Martins MC, Veras JEGLF, Uchoa JL, Pinheiro PNC, Vieira NFC, Ximenes LB. Food safety and the use of regional foods: the validation of a serial album. Rev Esc Enferm USP. 2012; 46(6):1354-61.

6. Ministério da Saúde (BR). Alimentos Regionais Brasileiros. Brasília: Ministério da Saúde; 2002.

7. Sampieri RH, Collado CF, Lucio PB. Metodologia de pesquisa. São Paulo: Mc Graw-Hill; 2013.

8. El-Nmer F, Salama AA, Elhawary D. Nutritional knowledge, attitude, and practice of parents and its impact on growth of their children. Menoufia Med J. [Internet] 2014 [cited 2014 Jan 28]; 27(3):612-6. Available from: http://www.mmj. eg.net/text.asp?2014/27/3/612/145529
9. Martins MC, Ximenes LB, Casimiro CF, Silveira VG, Frota MA. Estratégia educativa com enfoque nos hábitos alimentares de crianças: alimentos regionais. Cogitare Enferm. 2009; 14(3):463-9.

10. Marinho LAB, Costa-Gurgel MS, Cecatti JG, Osis MJD. Conhecimento, atitude e prática do autoexame das mamas em centros de saúde. RevSaúde Pública. 2003; 37(5):576-82.

11. Ell E, Oliveira e Silva D, Nazareno ER, Brandenburg A. Concepções de agricultores ecológicos do Paraná sobre alimentação saudável. Rev Saúde Pública. 2012; 46(2):218-25.

12. Paiva JB, Freitas MCS, Santos LAS. Hábitos alimentares regionais no Programa Nacional de Alimentação Escolar: um estudo qualitativo em um município do sertão da Bahia, Brasil. Rev Nutr. 2012; 25(2):191-202.

13. Ministério da Saúde (BR). Coordenação Geral da Política de Alimentação e Nutrição. Receitas Regionais para crianças de 6 a 24 meses. Brasília: Ministério da Saúde; 2010.

14. Figueiredo MFS, Rodrigues-Neto JF, Leite MTS. Modelos aplicados às atividades de educação em saúde. Rev Bras Enferm. 2010; 63(1):117-21.

15. Hassapidou M, Daskalou E, Paschaleri A, Papadopoulou S, Pagkalos I, Kaklamanou D, et al. A nutrition intervention program in preschool children in northern Greece. Public Health Nutr. 2012; (15):1524-5.

16. Zarnowiecki D, Sinn N, Petkov J, Dollman J. Parental nutrition knowledge and attitudes as predictors of 5-6-year-old children's healthy food knowledge. Public Health Nutr. 2011; 15(7):128490.

17. Ramos CI, Cuervo MRM. Programa Bolsa Família: a interface entre a atuação profissional e o direito humano a alimentação adequada. Ciênc Saúde Coletiva. 2012; 17(8):2159-68. 